\title{
PERSEPSI TERHADAP KEBIJAKAN PEMBERLAKUAN KEMBALI IZIN KAPAL IKAN BUATAN LUAR NEGERI DI PERAIRAN INDONESIA
}

\author{
Perception of Reenacting Permit Policy For Foreign \\ Made Fishing Vessels in Indonesian Water
}

\author{
*Rismutia Hayu Deswati, Irwan Muliawan, Risna Yusuf, dan Tenny Apriliani \\ Balai Besar Riset Sosial Ekonomi Kelautan dan Perikanan \\ Gedung BRSDM KP I Lt. 4, Jalan Pasir Putih Nomor 1 Ancol Timur, Jakarta Utara, Indonesia \\ Telp: (021) 64711583 Fax: 64700924 \\ Diterima tanggal: 21 Nopember 2020; Diterima setelah perbaikan: 28 Mei 2021; \\ Disetujui terbit: 25 Juni 2021
}

\begin{abstract}
ABSTRAK
Moratorium izin operasional kapal ikan yang dibangun di luar negeri, sebagaimana tertuang dalam Peraturan Menteri Kelautan dan Perikanan Nomor 56 Tahun 2014, merupakan kebijakan strategi untuk memberantas praktik IUU Fishing di perairan Indonesia. Tahun 2020 atau lima tahun setelah kebijakan tersebut, pemerintah mengeluarkan wacana untuk memberlakukan kembali izin operasional bagi kapal-kapal yang terkena moratorium. Wacana ini mengundang respon beragam dari para pengusaha perikanan yang terdampak. Untuk itu penelitian ini dilaksanakan, dengan tujuan untuk melakukan analisis terhadap persepsi pengusaha terhadap kebijakan tersebut, dengan harapan bahwa kebijakan lebih baik dapat dirumuskan untuk waktu yang akan datang. Data primer dikumpulkan melalui wawancara dengan pengusaha perikanan terdampak untuk mewakili pelaku usaha, dan pengawas perikanan untuk mewakili pelaksana kebijakan. Lokasi penelitian adalah DKI Jakarta, Bitung dan Bali, mewakili lokasi di mana kapal terdampak berlabuh Hasil penelitian menunjukkan terdapat 3 kategori persepsi responden terkait kebijakan pemberlakuan izin kapal ikan tersebut: (1) responden setuju pengaktifan kembali izin kapal ikan tersebut dengan catatan diikuti pembatasan alat tangkap yang digunakan, area operasi penangkapan ikan, ukuran kapal dan jenis komoditas hasil tangkapan, sebanyak 47\%; (2) responden setuju sebanyak $33 \%$, dan (3) responden tidak setuju sebanyak $20 \%$. Berdasar itu, kebijakan yang direkomendasikan adalah: (1) mengefektifkan komunikasi antara pemerintah dengan pemilik kapal dalam penyusunan kebijakan, (2) memperbaiki koordinasi hulu ke hilir ketika kebijakan telah dijalankan dan (3) menguatkan komitmen dan konsistensi pelaksanaan kebijakan oleh pelaku usaha dan pemerintah. Ketiga strategi tersebut dilaksanakan agar keberadaan kapal ikan buatan luar negeri itu dapat mendorong peningkatan produktifitas dan ekspor.
\end{abstract}

Kata Kunci: persepsi; moratorium; kebijakan; izin operasional; kapal ikan buatan luar negeri

\section{ABSTRACT}

The moratorium on the issuance of foreign-made fishing boat permits, as stated in the Minister of Marine Affairs and Fisheries Regulation Number 56 of 2014, is a strategy taken by the Indonesian government in respond to the practice of IUU fishing in Indonesian waters. In 2020, or five years after the policy, a discourse to reimpose the operational permits for vessels affected by the moratorium has been raised up. Various responses emerged from the affected fishery entrepreneurs. Therefore, the purpose of the research is to describe the perception of the entrepreneurs regarding the plan for better policy. Primary data were collected through interviews with the affected fishery entrepreneurs as representatives of business actors, and with fisheries supervisors at the research location as representatives of the government. The research were conducted in Jakarta, Bitung and Bali, which represent the locations of moratorium on dock permit. The results of this study pointed out the 3 categories of respondents' perceptions on the policy of fishing boat permit: 1). $47 \%$ of respondents agreed to the reactivation of the fishing boat license on condition with the restricted fishing gear, fishing area, vessel size and type of catch commodities; 2). $33 \%$ of respondents agreed; and (3) $20 \%$ of respondents disagreed. This study recommend: to involve the ship owner in policy making for better and more effective communication between government and ship owners 2). to encourage a good coordination in the upstream to downstream once the policies have been implemented, and; 3). to strengthen commitment and consistency between the business actors and government to implement the policies. Therefore, the presence of foreign-made fishing vessels will encourage the productivity and exports.

Keywords: perception; moratorium; policy; operational permit; foreign made fishing vessels 


\section{PENDAHULUAN}

Kebijakan moratorium izin operasional bagi kapal ikan buatan luar negeri dilaksanakan sebagai salah satu respon aktif pemerintah dalam menindaklanjuti praktik IIlegal, Unreported and Unregulated Fishing (IUU Fishing) yang dilakukan oleh kapal ikan buatan luar negeri di berbagai Wilayah Pengelolaan Perikanan Negara Republik Indonesia(WPPNRI). Kebijakan tersebut dipandang penting karena IUU Fishing telah mengakibatkan kerugian material mencapai $\mathrm{Rp} 30$ triliun dalam satu tahun (Mahabror dan Hidayat, 2018). Tidak hanya mengakibatkan kerugian finansial, praktik IUU Fishing menimbulkan dampak negatif pada kegiatan ekonomi dan sosial bukan hanya di Indonesia namun juga di negara lainnya. Dampak negatif pada kegiatan ekonomi adalah di mana nelayan lokal kalah bersaing dalam mendapatkan ikan karena teknologi kapal yang jauh tertinggal sehingga pendapatannya cenderung tidak bertambah. Sementara itu, dampak sosial terjadi terutama dalam bentuk timbulnya konflik antara nelayan legal dan nelayan illegal, yang kemudian memicu ketegangan hubungan diplomatik antar negara (Seisay et al., 2016).

Kebijakan moratorium tersebut diatur dalam Peraturan Menteri Kelautan dan Perikanan (Permen KP) Nomor 56 tahun 2014 tentang penghentian sementara (moratorium) perizinan usaha perikanan tangkap di wilayah pengelolaan perikanan negara Republik Indonesia hingga bulan April tahun 2015. Kementerian Kelautan dan Perikanan merevisi peraturan tersebut melalui Permen KP Nomor 10 Tahun 2015, yang isinya memperpanjang masa moratorium hingga bulan Oktober tahun 2015. Melalui Satuan Tugas 115, pemerintah selama waktu moratorium melakukan analisis dan evaluasi (anev) pada 1.132 kapal ikan buatan luar negeri yang masih ada di Indonesia dan kemudian menetapkan sanksi bagi para pemilik kapal tersebut.

Pada awal tahun 2020 muncul wacana pengaktifan kembali izin bagi kapal ikan buatan luar negeri untuk melakukan penangkapan ikan di perairan Indonesia. Rencana ini mengundang berbagai respon dari masyarakat, yang kemudian menjadi bahan pertimbangan bagi Pemerintah untuk mempertimbangkan realisasinya. Menurut Irianto dan Sidharta (2011), hukum tidak hanya berisi aturan normatif, tentang yang dilarang dan dibolehkan; tetapijuga berisi aturan kognitif. Menurut pandangan normatif perbuatan kriminal seperti mencuri dan membunuh dilarang di dalam hukum negara maupun adat, namun dalam pandangan kognitif definisi dari perbuatan-perbuatan tersebut berbeda-beda dari sisi politik dan budaya. Oleh karena itu, dalam rencana penerapan kebijakan baru ini pemahaman atau pandangan kognitif masyarakat dari suatu peraturan atau hukum merupakan salah satu aspek yang penting untuk dikaji.

Penelitian Herdiana (2018) menyatakan suatu kebijakan yang dihasilkan perlu diketahui oleh masyarakat agar kebijakan tersebut dapat dilaksanakan dan mendapatkan dukungan masyarakat. Kebijakan yang sudah dipahami masyarakat akan mendorong masyarakat secara sukarela mematuhinya dan mengawal pelaksanaannya sesuai dengan rambu-rambu yang ditetapkan. Belajar dari kebijakan-kebijakan sebelumnya, persepsi pelaku usaha yang terkait langsung dengan rencana pengaktifan kembali izin bagi kapal ikan buatan luar negeri menjadi sangat penting. Selain itu banyak bukti yang menunjukkan bahwa memasukkan pengetahuan sosial seperti persepsi ke dalam suatu desain kebijakan bisa membantu pemerintah dalam mengurangi konflik, meningkatkan kepatuhan yang lebih tinggi dan meminimalisir biaya sosial yang timbul pada masyarakat (Fricke, 1985; Lane \& Stephenson, 1995; McPhee \& Loveday, 2000; Shivlani \& Milon, 2000).

Tulisan ini bertujuan menjelaskan persepsi masyarakat terkait dengan rencana pengaktifan beroperasinya kapal ikan buatan luar negeri tersebut pada tahun 2020. Lokasi penelitian adalah Kota Bitung, Benoa dan Daerah Khusus Ibukota Jakarta. Lokasi tersebut merupakan tempat berlabuh kapal-kapal yang terkena moratorium tersebut. Penelitian dilakukan selama bulan April hingga Agustus tahun 2020.

Data yang digunakan dalam penelitian ini adalah data primer dan sekunder yang diperoleh dari berbagai sumber. Data primer diperoleh melalui survei dan wawancara dengan responden pengusaha kapal ikan dan pemerintah. Data sekunder diperoleh dari dari laporan pemerintah pusat Dirjen Perikanan Tangkap dan Dirjen Pengawasan Sumber Daya Kelautan dan Perikanan Kementerian Kelautan dan Perikanan serta laporan pemerintah daerah . Objek penelitian adalah pemilik kapal ikan buatan luar negeri sebanyak 20 orang dan petugas pengawas dari Direktorat Jenderal Pengawasan Sumber Daya 
Kelautan dan Perikanan sebanyak 12 responden. Data hasil penelitian dianalisis dengan pendekatan kualitatif dan fenomenanya dijelaskan secara deskriptif. Teknik analisis tersebut dimaksudkan untuk memberikan gambaran yang komprehensif tentang persepsi pelaku usaha terhadap rencana pengaktifan kembali kapal ikan buatan luar negeri sebagai kapal perikanan di Indonesia.

\section{Upaya Pemerintah RI Terkait IUU Fishing}

Sumber daya ikan yang melimpah menjadi daya tarik bagi nelayan asing untuk melakukan aktivitas illegal fishing di Indonesia (Muhammad, 2018). Penangkapan ilegal tersebut dilakukan dengan berbagai bentuk modus operandi. Kondisi tersebut menjadi dasar bagi pemerintah (Kementerian Kelautan dan Perikanan) mengeluarkan kebijakan penghentian sementara (moratorium) pemberian izin usaha perikanan tangkap yang tercantum dalam Peraturan Menteri Kelautan dan Perikanan (Permen KP) No 56 Tahun 2014. Pasal 1 ayat 2 pada peraturan Menteri tersebut mempertegas bahwa moratorium tersebut diberlakukan bagi kapal perikanan yang pembuatannya dilakukan di luar negeri. Pemberhentian sementara itu berlaku sejak ditandatanganinya Permen KP tersebut yaitu tanggal 30 November 2014 sampai dengan 30 April 2015. Proses moratorium tersebut berjalan secara cepat dan tegas di seluruh lokasi di Indonesia selama jangka waktu tersebut. Pada batas waktu terakhir, pemerintah merasa kebijakan tersebut belum menunjukkan dampak positif karena masih banyak pelanggaran yang dilakukan oleh kapal-kapal buatan luar negeri. Oleh karena itu, batas waktu moratorium diperpanjang kembali hingga 30 Oktober 2015 yang tercantum pada Permen KP No 10 Tahun 2015.

Kementerian Kelautan dan Perikanan melalui tim Satuan Tugas (Satgas) 115 melakukan proses analisa dan evaluasi pada 1.132 kapal ikan buatan luar negeri yang izinnya masih aktif selama masa moratorium.Kegiatan tersebut menetapkan terdapat 336 kapal masuk kategori blacklist dan 753 kapal masuk kategori whitelist. Pengkategorian tersebut selanjutnya diaplikasikan untuk penyelesaian kapal ikan buatan luar negeri (Gambar 1).

Berdasarkan Gambar 1, kapal ikan buatan luar negeri yang masuk kategori whitelist diberikan pilihan untuk deregistrasi (keluar dari daftar kapal perikanan Indonesia) dengan fisik kapal harus dikembalikan ke negara asal atau discrap dan alih fungsi diluar kapal perikanan. Kapal-kapal yang masuk kategori blacklist langsung menjalani proses hukum sesuai dengan hukum yang berlaku di Indonesia. Tim Satgas 115 terus melakukan kegiatan analisis dan evaluasi tersebut setiap tahunnya. Pada tahun 2018 jumlah kapal ikan buatan luar negeri yang masuk kategori blacklist hanya 88 kapal dari 336 kapal sedangkan sisanya masuk kategori sebaliknya.

Tabel 1 menunjukkan jumlah kapal ikan buatan luar negeri yang hingga saat ini terpantau masih berada di Indonesia sebanyak 445 kapal yang tersebar di berbagai kawasan perairan Indonesia. Kapal-kapal ini hanya berlabuh pada pelabuhan atau diletakkan di tengah laut di bawah pengawasan pemilik kapal dan pengawas perikanan.

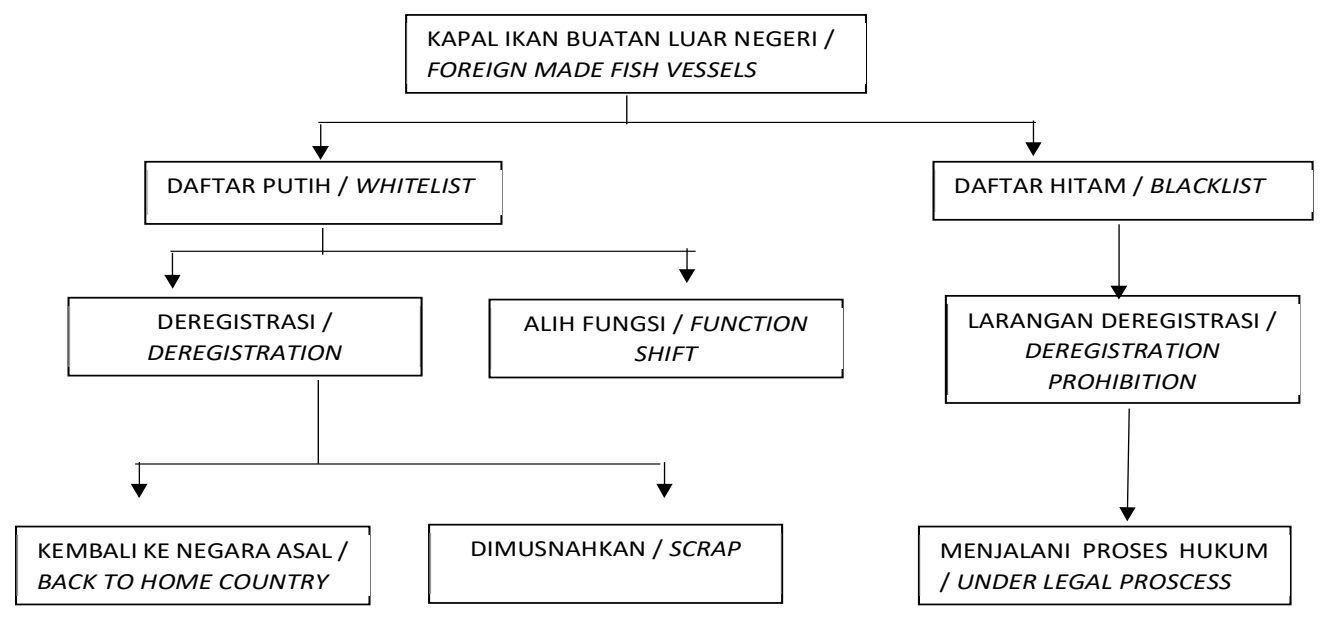

Gambar 1. Tindak Lanjut Hasil Analisis dan Evaluasi untuk Kapal Ikan Buatan Luar Negeri. Figure 1. Follow Up The Results of Analysis and Evaluatian for Foreign-made Fishing Vessels.

Sumber: Direktorat Jenderal Pengawasan Sumber Daya Kelautan dan Perikanan, 2016/ Source: Directorate General Of Marine And Fisheries Resources Surveillance, 2016 
Tabel 1. Status Kapal Ikan Buatan Luar Negeri Hasil Analisis dan Evaluasi Satgas 115 Tahun 2020. Table 1. Status of Foreign Made Fishing Vessels from the Results of Analysis and Evaluation Satgas 115, 2020.

\begin{tabular}{|c|c|c|c|c|c|c|}
\hline \multirow[b]{2}{*}{ No } & \multirow[b]{2}{*}{$\begin{array}{l}\text { Kondisi Kapal/ } \\
\text { Ship Condition }\end{array}$} & \multirow[b]{2}{*}{$\begin{array}{l}\text { Jumlah I } \\
\text { Total }\end{array}$} & \multicolumn{4}{|c|}{ Keterangan/Information } \\
\hline & & & $\begin{array}{l}\text { Telah } \\
\text { Deregistrasi/ } \\
\text { Deregistrated }\end{array}$ & $\begin{array}{l}\text { Sedang Proses } \\
\text { Deregistrasi/ } \\
\text { In Deregistration } \\
\text { Process }\end{array}$ & $\begin{array}{l}\text { Daftar } \\
\text { Hitam/ } \\
\text { Blacklist }\end{array}$ & $\begin{array}{c}\text { Belum } \\
\text { Deregistrasi/ } \\
\text { Has Not Been } \\
\text { Deregistration }\end{array}$ \\
\hline \multirow[t]{3}{*}{1.} & $\begin{array}{l}\text { Masih berada di Indonesia/ } \\
\text { Still in Indonesia }\end{array}$ & 448 & & & & \\
\hline & Ada di Pelabuhan/At Port & 445 & 127 & & 86 & 232 \\
\hline & Inkracht & 3 & & & & \\
\hline \multirow[t]{5}{*}{2.} & $\begin{array}{l}\text { Sudah tidak ada di Indonesia/ } \\
\text { Does not exist in Indonesia }\end{array}$ & 331 & & & & \\
\hline & $\begin{array}{l}\text { Sudah ke Luar Negeri/ } \\
\text { Already abroad }\end{array}$ & 210 & 163 & & & 47 \\
\hline & $\begin{array}{l}\text { Sudah Discrap/Already } \\
\text { scraped }\end{array}$ & 103 & 20 & & 1 & 82 \\
\hline & $\begin{array}{l}\text { Tenggelam atau } \\
\text { Ditenggelamkan/Drowned }\end{array}$ & 10 & & & 1 & 9 \\
\hline & Terbakar/On fire & 8 & & & & 8 \\
\hline \multirow[t]{2}{*}{3.} & Alih Fungsi/Functional shift & 3 & & & & 3 \\
\hline & Jumlah/Total & 782 & 310 & & 88 & 384 \\
\hline
\end{tabular}

Sumber: Direktorat Jenderal Pengawasan Sumber Daya Kelautan dan Perikanan, 2020/

Source: Directorate General of Marine And Fisheries Resources Surveillance, 2020

Tabel 1 menunjukkan kondisi kapal ikan buatan luar negeri yang terkena moratorium dimana sebanyak 232 kapal dari 445 kapal yang ada di pelabuhan belum melakukan deregistrasi dengan berbagai alasan diantaranya berharap bisa digunakan kembali sebagai kapal ikan, belum ada kepastian penggunaannya dan merasa rugi jika melakukan proses deregistrasi.

Kebijakan moratorium yang diatur dalam Permen KP Nomor 56 tahun 2014 dan Permen KP Nomor 10 Tahun 2015 juga didukung oleh beberapa kebijakan lainnya yaitu penghentian kegiatan alih muatan (transhipment) di tengah laut yang tertuang dalam Permen KP Nomor 57 tahun 2014. Terdapat pula peraturan yang mengatur aparatur sipil negara yang mendukung dalam pemberantasan illegal fishing tertuang dalam PERMEN KP No 58/permen-KP/2014. Dengan adanya penerapan peraturan atau kebijakan tersebut dapat mengurangi terjadinya kasus Illegal Fishing di Indonesia yang selama ini mengakibatkan terancamnya keberlanjutan stok perikanan Indonesia dan merugikan secara finansial (Syahrani, Al Musadieq \& Darmawan, 2017).

Menteri Kelautan dan Perikanan Edhy Prabowo sejak dilantik pada Oktober tahun
2019 memutuskan untuk melakukan peninjauan kembali sejumlah aturan dan rencana penyederhanaan dari aturan - aturan tersebut, dimana moratorium kapal ikan buatan luar negeri menjadi salah satu kebijakan yang ditinjau ulang. Menurut Menteri Kelautan dan Perikanan banyak kapal ikan buatan luar negeri yang notabene sudah dibeli dan menjadi milik orang Indonesia tidak bisa beroperasional karena terbentur aturan pada Permen KP No 56 tahun 2014, sehingga jika tidak ada tindakan tegas maka bisa mematikan usaha perikanan tangkap (Nuraini, 2020).

Rencana pemberlakuan kembali izin kapal ikan buatan luar negeri didasari oleh beberapa alasan, salah satunya yaitu dalam rangka pemenuhan kuota tangkapan ikan tuna di laut lepas. Indonesia telah tercatat menjadi anggota Organisasi Pengelolaan Perikanan Regional atau Regional Fisheries Management Organisations (RFMOs) yang melingkupi perairan Indonesia seperti Indian Ocean Tuna Commission (IOTC), Commission on Conservation of Southern Bluefin Tuna (CCSBT) dan Western and Central Pacific Fisheries Commission (WCPFC). Namun demikian, jumlah armada perikanan yang dimiliki Indonesia terutama di laut lepas yang juga masuk area WPP 717 masih belum maksimal (Gambar 2). 


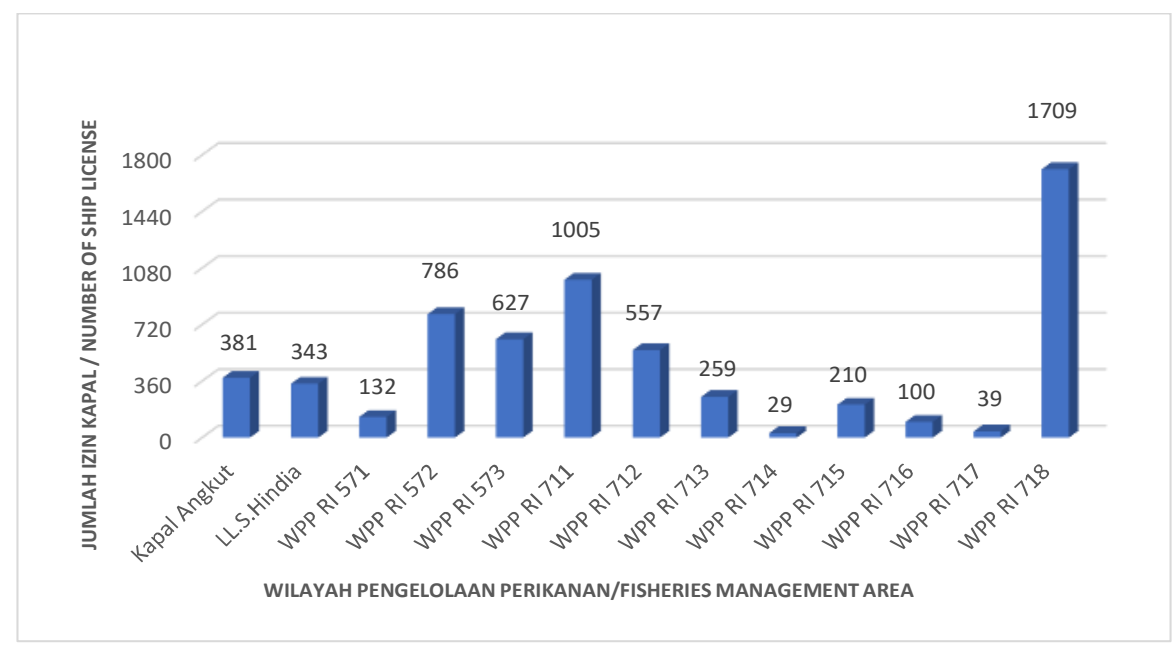

Gambar 2. Sebaran Kapal Perikanan Menurut WPP di WPPNRI.

Figure 2. Distribution of Fishing Vessels According to WPP at WPPNRI.

Sumber: Direktorat Jenderal Perikanan Tangkap, 2020.

Source: Directorate General of Capture Fisheries

Gambar 2 menunjukkan jumlah kapal di WPP 716 dan 717 memiliki volume tangkapan yang masih di bawah kuota penangkapan tuna yang ada. Melihat status yang digambarkan pada gambar tersebut menjadi pertimbangan bagi pemerintah untuk memberdayakan kembali kapal-kapal ikan buatan luar negeri yang dari sisi teknologi dan ukuran kapal bisa mendukung penangkapan tuna di laut lepas tersebut.

\section{Pengetahuan Pelaku Usaha Perikanan Terhadap Rencana Pemberlakuan Kembali Izin Kapal Ikan Buatan Luar Negeri}

Rencana pemberlakuan kembali izin kapal ikan buatan luar negeri belum dirilis secara resmi oleh pemerintah, namun demikian informasi tersebut sudah beredar di kalangan pelaku usaha terutama pemilik kapal. Dari perspektif demokrasi, suatu kebijakan publik yang akan diimplementasikan harus mendapatkan dukungan dari publik yang bisa digali dengan berbagai metode aspirasi seperti konsultasi publik, diskusi kelompok terfokus dan dengar pendapat. Informasi dari publik sangat penting karena kemampuan wawasan, pengetahuan dan penguasaan pembuat kebijakan tentang masalah-masalah publik terkadang terbatas (Irawati dan Widaningrum, 2015).

Berdasarkan hasil wawancara dengan para pemilik kapal ikan buatan luar negeri di 3 lokasi penelitian dapat disimpulkan bahwa selama ini informasi mengenai rencana pemberlakuan kembali izin kapal ikan buatan luar negeri hanya diperoleh dari informan yang tidak resmi. Akses untuk mendapatkan informasi dari Kementerian Kelautan dan Perikanan dirasa sangat tertutup dan terbatas. Sebanyak 7 orang pemilik kapal ikan di Jakarta menginformasikan bahwa mereka mengetahui rencana tersebut dari perbincangan dengan sesama pemilik kapal namun belum mendapatkan informasi langsung dari Direktorat Jenderal Pengawasan Sumber Daya Kelautan dan Perikanan. Menurut mereka sebaiknya dilakukan audiensi sebelum rencana kebijakan tersebut ditetapkan agar bisa tepat sasaran.

Para pemilik kapal ikan di Bitung sebanyak 7 orang menyatakan bahwa pengetahuan mereka terkait informasi rencana pemberlakuan kembali izin kapal ikan bagi kapal-kapal yang terkena moratorium belum masih sebatas wacana yang diperoleh dari perbincangan tidak resmi antar sesama pelaku usaha. Informasi tersebut belum resmi dan belum tertulis sehingga mereka juga belum mengambil langkah apapun dalam menindaklanjuti rencana tersebut. Pernyataan yang serupa juga disampaikan oleh 6 responden pemilik kapal ikan di Benoa, Bali yang menyatakan bahwa rencana pemberlakuan kembali izin kapal sangat dibutuhkan oleh mereka mengingat mayoritas kapal mereka semua dihentikan operasionalnya.

Wawancara dengan pengawas perikanan menunjukkan proses yang dilakukan Kementerian Kelautan dan Perikanan terkait rencana ini masih dalam tahap kajian dan penelitian, dimana dalam proses tersebut dilakukan diskusi dan sosialisasi 
terbatas internal. Perbedaan proses penerbitan kebijakan yang dilakukan KKP saat ini dengan periode sebelumnya terletak pada proses sosialisasi yang senantiasa dilakukan di tiap tahapan rencana kebijakan. Sosialisasi tidak memiliki keterkaitan langsung dalam proses kebijakan publik sehingga tidak mengubah kedudukan setiap tahapan dalam proses kebijakan publik. Namun sosialisasi memiliki kedudukan yang strategis dalam terlaksananya implementasi kebijakan secara benar sebagaimana tujuan kebijakan yang telah dirumuskan dalam proses formulasi kebijakan (Herdiana, 2018).

Rencana pemberlakuan kembali izin kapal ikan buatan luar negeri perlu disampaikan secara lugas, menyeluruh dan transparan agar informasi yang diterima memiliki kesamaan antara pemerintah dan pelaku usaha pemilik kapal ikan secara menyeluruh. Pengetahuan yang lengkap dari para responden menjadi satu hal penting dalam pembentukan persepsi responden yang bisa menjadi dasar pertimbangan pemerintah dalam memutuskan kebijakan sehingga bisa tepat sasaran.

\section{Persepsi Pemilik Kapal Ikan terhadap Rencana Pemberlakuan Kembali Izin Kapal Ikan Buatan Luar Negeri}

Persepsi adalah proses memberikan makna pada stimuli inderawi dimana responden menafsirkan informasi berdasarkan alat indera masing-masing sehingga memberikan hasil yang berbeda-beda. Stimuli atau informasi pada kasus ini adalah rencana pengaktifan kembali ijin kapal ikan buatan luar negeri sebagai kapal perikanan di Indonesia. Berbagai rumusan teknis seperti penyusunan naskah akademik dan rencana aksi untuk rencana tersebut sudah mulai diajukan dan dianalisis namun hingga saat ini belum ada keputusan resmi yang dikeluarkan pemerintah. Persepsi pelaku usaha terutama pemilik kapal menjadi salah satu nilai penting yang menjadi dasar pertimbangan pemerintah untuk merumuskan kebijakan baru yang akan menggantikan kebijakan sebelumnya. Hal ini senada dengan apa yang disampaikan Brookz dan Manza (2007) yang membuktikan bahwa opini atau persepsi publik memberikan pengaruh yang besar bagi penerapan kebijakan publik.

Berbicara mengenai rencana kebijakan pastinya akan menimbulkan respon baik positif maupun negatif karena berangkat dari persepsi yang juga berbeda-beda. Hal ini juga terlihat pada hasil penelitian yang menunjukkan persepsi yang beragam dari para pemilik kapal ikan buatan luar negeri terhadap rencana pengaktifan kembali ijin usaha penangkapan bagi mereka. Keragaman persepsi tersebut terjadi karena masing-masing pemilik kapal mendapatkan informasi dari sumber yang berbeda diantaranya dari sosial media, media elektronik dan hasil rapat dari para pengambil kebijakan. Informasi yang ditampilkan masing-masing sumber tidak sama dan terkadang melenceng dari informasi sebenarnya, ditambah pula tidak semua pemilik kapal melakukan pengecekan informasi lebih lanjut. Pembentukan persepsi juga dipengaruhi oleh lokasi dari para pemilik kapal ikan yang menjadi responden serta bentuk adaptasi yang telah mereka lakukan selama lima tahun terakhir.

\section{Persepsi Pemilik Kapal Ikan di DKI Jakarta Terhadap Rencana Pemberlakuan Kembali Izin Kapal Ikan Buatan Luar Negeri}

Kapal ikan buatan luar negeri yang terkena moratorium di Daerah Khusus Ibukota Jakarta yang hingga saat ini masih ada fisiknya dan berlabuh di area Jakarta dan sekitarnya tidak sampai 10 kapal dengan ukuran di atas 100 GT. Selama 5 tahun pemilik kapal hanya melakukan perawatan dan penjagaan pada kapal-kapal yang terkena moratorium dengan harapan suatu saat bisa digunakan kembali. Respon yang diberikan para pemilik kapal saat mengetahui rencana pengaktifan kembali ijin kapal ikan buatan luar negeri terbagi menjadi dua kategori yaitu setuju dengan ruang lingkup yang dibatasi dan tidak setuju dengan rencana tersebut. Sebanyak 5 dari 7 pemilik kapal setuju dengan rencana tersebut dengan masukan berupa persyaratan diantaranya kebijakan ini harus memiliki kepastian hukum yang jelas bagi pemilik kapal; diawali dengan adanya sosialisasi dan komunikasi publik dengan pelaku usaha terkait; dan perlu adanya petunjuk teknis yang disepakati antara KKP dengan pemilik kapal mengenai aturan penangkapan seperti alat tangkap, area penangkapan dan komoditas hasil tangkapan. Sisanya menyatakan tidak setuju dengan rencana tersebut karena berpeluang merugikan perusahaan-perusahaan yang sudah beralih menggunakan kapal ikan kecil untuk pemenuhan produksi lokal. Kondisi tersebut ditakutkan menimbulkan konflik baru antar nelayan dan juga perusahaan pemilik kapal ikan. 
Pengawas perikanan dari Pangkalan PSDKP Jakarta sebanyak 4 orang ketika diwawancara menyatakan pada dasarnya persepsi mereka setuju untuk pemberlakuan kembali karena tidak semua perusahaan yang memiliki kapal ikan buatan luar negeri melanggar hukum dan terlibat IUU Fishing. Saran yang disampaikan pemberian izin harus melihat pada track record perusahaan dalam perizinan usaha juga dan perlu adanya penambahan aplikasi khusus secara digital yang bisa digunakan sehingga bisa dilakukan pengawasan dan perizinan yang lebih ketat dan selektif serta objektif sehingga laut Indonesia tetap aman dari IUU Fishing.

\section{Persepsi Pemilik Kapal Ikan di Kota Bitung terhadap Rencana Pemberlakuan Kembali Izin Kapal Ikan Buatan Luar Negeri}

Pelaku usaha perikanan di Kota Bitung merupakan salah satu yang terdampak cukup besar dari adanya moratorium kapal ikan buatan luar negeri. Kebijakan tersebut telah menambah jumlah pengangguran kurang lebih 2.910 orang yang berasal dari $A B K$, pengurus dan nakhoda dari kapal-kapal yang dilarang tersebut (Nurlaili, Muhartono, \& Hikmayani, 2016). Dampak negatif moratorium juga terasa pada UPI yang mengandalkan pasokan bahan baku utama dari kapal-kapal tersebut. Menurut Hikmayani, Rahadian, Nurlaili, \& Muhartono (2015), terjadi penurunan produksi hingga $50 \%$ yang akhirnya berdampak pada penurunan penyerapan tenaga kerja sebesar $80 \%$.

Terkait dengan rencana pemberlakuan kembali izin kapal ikan buatan luar negeri 7 orang pemilik kapal yang menjadi responden menyatakan setuju dengan rencana tersebut, namun dengan adanya sejumlah masukan persyaratan bagi KKP. Persyaratan tersebut diantaranya:

1. Pemberlakuan kembali izin operasional hanya diberikan bagi kapal-kapal ikan yang terkena moratorium bukan untuk kapal baru

2. Perlu adanya petunjuk teknis dalam mengaplikasikan kebijakan namun sebaiknya tidak perlu ada pembatasan dalam penggunaan jenis alat tangkap tertentu , ukuran kapal dan area penangkapan yang ditakutkan akan mengundang konflik

3. Perlu adanya dukungan pemerintah untuk perbaikan kapal dan biaya operasional awal saat kapal kembali melaut
Empat orang responden lainnya adalah pengawas perikanan di Kota Bitung yang menyatakan perlu adanya kebijakan-kebijakan atau petunjuk teknis untuk melengkapi kebijakan baru tersebut untuk menjaga kondisi di lapangan tetap aman dan minim konflik. Pada dasarnya dari pihak Pangkalan PSDKP Bitung setuju dengan rencana tersebut namun perlu diperketat mulai dari perizinan dan pengawasan yang bukan hanya di laut namun juga di darat. Oleh karena itu perlu adanya sinergitas yang solid antar pihakpihak yang terkait dalam hal ini pemilik kapal, Direktorat Jenderal Perikanan Tangkap, Direktorat Jenderal Pengawasan Sumber Daya Kelautan dan Perikanan serta pemerintah daerah.

\section{Persepsi Pemilik Kapal Ikan di Bali terhadap Rencana Pemberlakuan Kembali Izin Kapal Ikan Buatan Luar Negeri}

Provinsi Bali adalah salah satu lokasi yang memiliki jumlah kapal ikan buatan luar negeri cukup banyak dengan alat tangkap mayoritas yang digunakan longline dan handline sehingga mayoritas yang ditangkap adalah tuna dan sejenisnya. Usaha perikanan di daerah ini juga terdampak dari kebijakan moratorium tersebut baik negatif maupun positif. Kebijakan tersebut telah menurunkan jumlah produksi perikanan tangkap di Bali mencapai 19,2 \% (Saptanto, Yusuf, Apriliani, \& Arthatiani, 2015).

Hasil wawancara yang dilakukan dengan para pemilik kapal di Benoa sebanyak 6 orang pada bulan Agustus 2020 menunjukkan bahwa rencana kebijakan pemberlakuan kembali izin kapal ikan buatan luar negeri sebaiknya memang segera disahkan karena keberadaan kapal-kapal tersebut terutama yang ada di Bali tidak menyalahi aturan baik dari sisi dokumen maupun praktek penangkapan ikan di lokasi . Persepsi semua responden setuju dengan adanya rencana tersebut namun diikuti dengan adanya pembatasan di salah satu aspek, yaitu komoditas hasil tangkapan. Pembatasan komoditas hasil tangkapan hanya untuk komoditas ekspor bisa berpeluang meningkatkan produksi UPI karena adanya peningkatan pasokan bahan baku. Kondisi ini menghasilkan efek multiplier bagi masyarakat secara lebih luas diantaranya meningkatnya penyerapan tenaga kerja, volume ekspor dan juga pendapatan pemerintah. Pemilik kapal juga akan melakukan penyesuaian kapal dan alat tangkap untuk mengakomodir pembatasan ini sehingga dampaknya keberlanjutan sumberdaya ikan tetap terjamin. 
Sementara itu 4 orang pengawas perikanan yang diwawancara juga setuju untuk pemberlakuan kembali demi bergeraknya kembali perekonomian di Bali dari sektor perikanan. Baik dari pihak Pelabuhan maupun pengawas perikanan sepakat bahwa perlu adanya sinergitas yang baik antar semua pihak yang terlibat sehingga apa yang menjadi kebijakan sudah merupakan hasil kesepakatan bersama.

Adanya perbedaan persepsi yang terbentuk di masing-masing lokasi penelitian dipengaruhi berbagai faktor seperti ukuran kapal yang dimiliki, komoditas hasil tangkapan dan keinginan serta kebutuhan dari tiap responden yang berbeda-beda. Hasil penelitian menunjukkan bahwa terdapat 3 jenis persepsi dari pelaku usaha pemilik kapal di lokasi penelitian terhadap rencana pemberlakuan kembali izin kapal ikan buatan luar negeri. Jenis-jenis persepsi tersebut adalah:

1. Setuju untuk pengaktifan kembali dengan ruang lingkup yang terbatas. Artinya mulai dari ukuran kapal, area penangkapan, alat tangkap, komoditas tangkapan, ABK dan nakhoda semua dibatasi yang akan diatur dalam petunjuk teknis. Persepsi ini dikemukakan oleh 15 responden dari total 32 responden yang diwawancara.

2. Setuju untuk pemberlakuan kembali dengan ruang lingkup tanpa batas. Artinya ukuran kapal, area penangkapan, alat tangkap, komoditas tangkapan, ABK dan nakhoda tidak dibatasi selama sudah mengantongi izin. Persepsi ini dipilih oleh 11 responden dari total 32 responden.

3. Tidak setuju untuk pemberlakuan kembali selamanya. Artinya tidak ada lagi peluang untuk kapal-kapal ikan buatan luar negeri baik yang terdampak moratorium atau kapal baru di Indonesia. Persepsi ini muncul dari 6 responden dari total 32 responden.

Pada Gambar 3 terlihat dari 3 lokasi penelitian terpilih diperoleh hasil bahwa sebanyak $47 \%$ responden setuju dengan rencana kebijakan tersebut namun perlu adanya batasan dan persyaratan untuk menjaga ketersediaan stok ikan di perairan Indonesia. Batasan-batasan ini yang perlu disusun ulang bisa dalam bentuk petunjuk teknis atau mungkin kebijakan baru dalam bentuk peraturan menteri yang erat kaitannya dengan rencana ini. Dilihat pada Gambar 3 tersebut bisa menjadi salah satu dasar pertimbangan pengambil kebijakan untuk melakukan audiensi awal terutama yang mewakili masing-masing kategori persepsi.

\section{Penyamaan Persepsi Terhadap Rencana Pemberlakuan Kembali Izin Kapal Ikan Buatan Luar Negeri}

Perbedaan persepsi bisa dipengaruhi oleh dua faktor yaitu faktor pengetahuan (kognitif) dan

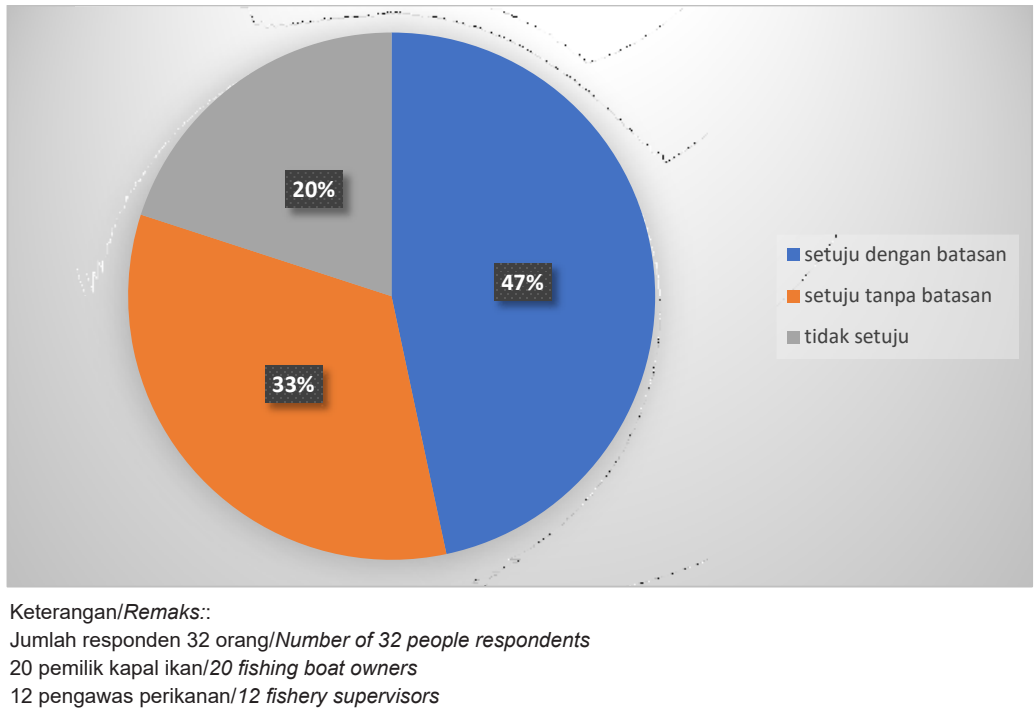

Gambar 3. Persentase Persepsi Responden Terhadap Rencana Pemberlakuan Kembali Izin Kapal Ikan Buatan Luar Negeri.

Figure 3. Percentage of Respondent Perception About The Plan to Reenacting Foreign Made Fishing Vessels Permits.

Sumber: Data primer diolah, 2020/Source: Primary data processed, 2020 
faktor lingkungan. Hasil penelitian menggambarkan adanya perbedaan persepsi mengenai teknis dari pemberlakuan kembali izin kapal ikan buatan luar negeri ini. Menurut konsep persepsi, benar dan salah suatu hal terasa membingungkan karena berkaitan dengan kemampuan masing-masing orang dalam mengidentifikasi dan menyimpulkan hal tersebut. Pemerintah diharapkan bisa berperan aktif untuk mengakomodir semua pendapat dan harapan yang ada terkait kebijakan ini agar bisa terbentuk persepsi yang sama.

Pemerintah sebaiknya melakukan beberapa tahapan kegiatan yang melibatkan peran serta pelaku usaha perikanan dan masyarakat sebelum suatu kebijakan diputuskan dan diimplementasikan. Tahap pertama melakukan sosialisasi rencana kebijakan dengan menggunakan bentuk komunikasi yang baik dari pemberi pesan kepada penerima pesan (pelaku usaha atau masyarakat). Salah satu bentuk yang bisa diterapkan dengan adanya dengar pendapat secara dua arah agar persepsi dari masing-masing pihak bisa diakomodir. Tahapan tersebut akan menghasilkan keputusan yang diterima semua pihak yang terlibat dengan peluang resiko yang paling kecil.

Menurut Mariana (2015) ada dua
pendekatan yang bisa dilakukan untuk
memberdayakan masyarakat atau dalam
konteks ini adalah pemilik kapal, yakni: pertama, pendekatan struktural. Pendekatan struktural dilakukan dengan cara mengadvokasikan berbagai instrumen hukum dan kelembagaan yang memberi peluang bagi masyarakat untuk berpartisipasi, mengakses informasi, dan mengontrol akuntabilitas pemerintahan. Kedua, pendekatan sosiokultural. Pendekatan ini dilakukan melalui proses pendidikan, pengorganisasian, dan pendampingan masyarakat agar masyarakat dapat mengindentifikasi dan mengartikulasi aspirasi dan kepentingan mereka, sehingga potensi manipulasi aspirasi dan kepentingan masyarakat dapat diminimalkan. Pendekatan-pendekatan ini bisa diaplikasikan oleh pemerintah dalam tahapan selanjutnya pada proses penetapan rencana kebijakan pemberlakuan kembali izin kapal ikan buatan luar negeri. Pemerintah bisa mengikutsertakan akademisi untuk melakukan pendampingan bagi pemilik kapal ikan dalam merumuskan dan menyampaikan konsepkonsep dan wawasan baru yang bisa digunakan pemilik kapal dan masyarakat dalam merumuskan ulang kebijakan tersebut.
Rencana pemberlakuan kembali izin kapal ikan buatan luar negeri merupakan salah satu agenda yang dinantikan baik oleh pelaku usaha, masyarakat umum maupun pemerintah, karena membutuhkan waktu penantian yang cukup lama. Rencana tersebut mengundang persepsi pro dan kontra yang berasal dari pemilik kapal ikan dan pemerintah yang bertugas di lapangan.

Berdasarkan temuan lapang teridentifikasi 3 (tiga) jenis persepsi mengenai rencana kebijakan ini yaitu: setuju pemberlakuan kembali izin operasional penangkapan dengan ruang lingkup yang dibatasi; setuju pemberlakuan kembali izin operasional penangkapan dengan ruang lingkup tanpa batas dan tidak setuju untuk pemberlakuan kembali izin operasional penangkapan ikan untuk selamanya. Dari ketiga kategori persepsi tersebut mayoritas berpendapat setuju dengan rencana pemberlakuan kembali izin kapal ikan buatan luar negeri dengan adanya batasan di sisi ukuran kapal, penggunaan alat tangkap, area penangkapan dan komoditas hasil tangkapan.

Perbedaan persepsi dalam menyikapi rencana pemberlakuan kembali izin kapal ikan buatan luar negeri muncul sebagai respon yang wajar karena didasari pengalaman yang berbedabeda dari tiap pemilik kapal ikan buatan luar negeri di masa lalu. Namun perbedaan persepsi ini jangan dipandang sebagai masalah yang kemudian justru menghambat proses rencana kebijakan ini. Persepsi yang beragam bisa menjadi dasar pertimbangan bagi pemerintah untuk menentukan kebijakan yang sesuai dan bisa diterima oleh masing-masing pihak yang berkepentingan.

Pada intinya mayoritas responden memiliki persepsi yang sama untuk setuju mengenai rencana pemberlakuan kembali izin kapal ikan buatan luar negeri tersebut. Persepsi yang sama tersebut bisa menjadi kunci awal bagi pemerintah untuk melakukan tahapan selanjutnya dalam penyusunan kebijakan. Pemerintah dan pemilk kapal juga harus melakukan kesepakatan untuk saling menjaga komitmen dalam menjalankan apapun kebijakan yang nantinya akan diputuskan.

Dikaitkan dengan proses kebijakan publik mulai dari perancangan kebijakan, implementasi hingga evaluasi maka sosialisasi suatu kebijakan adalah hal utama yang harus dikedepankan oleh pemerintah agar pemilik kapal dapat mengetahui dan memahami maksud dan tujuan dari 
penyelenggaraan kebijakan mengenai kapal ikan buatan luar negeri tersebut. Bentuk sosialisasi yang bisa dilakukan diantaranya dengan melakukan komunikasi publik atau dengar pendapat antara pengambil kebijakan dengan pemilik kapal kemudian dilanjutkan dengan perumusan bersama rencana naskah akademik sebagai dasar untuk menerbitkan peraturan Menteri terkait kapal ikan buatan luar negeri tersebut.

\section{IMPLIKASI KEBIJAKAN}

Rencana kebijakan pemberlakuan kembali izin operasional bagi kapal ikan buatan luar negeri harus mendukung peningkatan produksi perikanan tangkap dan UPI yang ada tanpa meningkatkan kembali potensi terjadinya IUU Fishing di perairan Indonesia. Rencana ini harus diawali dengan komunikasi baik antara pemerintah dan pelaku usaha terkait dan didukung dengan petunjuk teknis dalam mengaplikasikannya di lapang. Dokumen tambahan tersebut diperlukan untuk mengatur agar kebijakan tersebut bisa berjalan sesuai peraturan yang sudah ditetapkan. Di sisi lain, pemilik kapal ikan harus mendukung kebijakan tersebut sesuai dengan peraturan yang sudah disepakati dan ditetapkan. Dukungan pengusaha tersebut bisa diwujudkan dalam bentuk pakta integritas atau MoU dengan pemerintah sehingga aturan dan sanksi diakui secara legal.

Kebijakan pemberlakuan kembali izin kapal ikan buatan luar negeri akan menimbulkan efek ganda (multiplier effect) yang cukup besar, diantaranya peningkatan penyerapan tenaga kerja baik sebagai $A B K$ maupun tenaga kerja UPI dan juga usaha-usaha pendukung lainnya. Dukungan dan komitmen tinggi antara pemerintah, pelaku usaha perikanan dan masyarakat diperlukan agar kebijakan ini bisa berjalan sesuai yang diharapkan tanpa memicu potensi konflik baru.

\section{UCAPAN TERIMA KASIH}

Penulis menyampaikan rasa terima kasih kepada Pangkalan PSDKP Kota Bitung, Pangkalan PSDKP DKI Jakarta, Pos Pelabuhan Benoa yang sudah banyak membantu dalam proses pengumpulan data hingga terbentuknya tulisan ini. Tak lupa terima kasih yang mendalam juga disampaikan kepada para pemilik kapal ikan buatan luar negeri yang bersedia diwawancara dan memberikan respon positif kepada tim Peneliti.

\section{PERNYATAAN KONTRIBUSI PENULIS}

Dengan ini kami menyatakan bahwa kontribusi masing-masing penulis terhadap pembuatan karya tulis adalah: Rismutia Hayu Deswati dan Irwan Muliawan sebagai kontributor utama, Tenny Apriliani dan Risna Yusuf sebagai kontributor anggota. Penulis menyatakan bahwa telah melampirkan surat pernyataan kontribusi penulis.

\section{DAFTAR PUSTAKA}

Arthatiani, F., \& Apriliani, T. (2015). Dampak kebijakan moratorium kapal eks asing terhadap kondisi perikanan tuna: Studi kasus di DKI Jakarta. Jurnal Kebijakan Sosial Ekonomi Kelautan dan Perikanan, 5 (2), 71-82. DOI: http://doi:10.15578/ jksekp.v5i2.1017

Brookz, C \& Manza, Z. (2007). Why Welfare States Persist: The Importance of Public Opinions in Democracies. Chicago, AS: University of Chicago Press

[DJPT] Direktorat Jenderal Perikanan Tangkap. (2020). Data Sebaran Kapal Perikanan Menurut Wilayah Pengelolaan Perikanan. Statistik Perizinan dan Kenelayanan Kementerian Kelautan dan Perikanan. Jakarta, ID: Kementerian Kelautan dan Perikanan

Fricke, P. (1985). Use of sociological data in the allocation of common property resources. Marine Policy 9, 39-52. Retrieved from: https://dlc.dlib. indiana.edu/dlc/bitstream/handle/10535/7991/ Use $\% 20$ of $\% 20$ Sociological\%20Data $\% 20$ in $\% 20$ the $\% 20$ Allocation $\% 20$ of $\% 20$ Common $\% 20$ Property\%20Resources. pdf?sequence=1\&isAllowed=y

Herdiana, D. (2018). Sosialisasi Kebijakan Publik : Pengertian dan Konsep Dasar. Jurnal IImiah Wawasan Insan Akademik, 1(3), 13-25. Retrieved from: https://dianherdiana.com/2018/12/19/ sosialisasi-kebijakan-publik-pengertian-dan-konsep-dasar/

Hikmayani, Y., Rahadian, R., Nurlaili dan Muhartono, R. (2015). Efektivitas Pemberlakuan Moratorium Kapal Eks Asing dan Transhipment terhadap Kinerja Usaha Penangkapan Ikan. Jurnal Kebijakan Sosial Ekonomi Kelautan dan Perikanan, 5 (2). 101-112. DOI: http://dx.doi. org/10.15578/jksekp.v5i2.1021

Irawati, E dan Widaningrum, A. (2015). Modul Pelatihan Analis Kebijakan. Jakarta, ID: Pusat Pembinaan Analis Kebijakan Lembaga Administrasi Negara

Lane, D. E., Stephenson, R. L., (1995). Fisheries management science: the framework to link biological, economic and social objectives in 
fisheries management. Aquat. Living Resour. 8(3), 215-221. DOI: https://doi.org/10.1051/ alr:1995021

Mahabror, D dan Hidayat, J. J. (2018). Analisis Kerugian Ekonomi Akibat Illegal Fishing di Zona Ekonomi Eksklusif Perairan Natuna. Dalam W.A. Nugraha, A. Romadhon dan Insafitri (Ed.) Prosiding Seminar Nasional Kelautan dan Perikanan IV (263 - 270). Madura, ID: Fakultas Pertanian Universitas Trunojoyo

Mariana, D. (2015). Partisipasi Masyarakat dalam Proses Kebijakan. Jurnal IImu Pemerintahan Cosmogov, 1(2), 216-229. DOI: https://doi.org/10.24198/ cosmogov.v1i2.11834

McPhee, D. P., Loveday, T. D., (2000). The Queensland fishing industry and ecologically sustainable development. In: Hale, P., Petrie, A., Moloney, D., Sattler, P. (Eds.), Management for Sustainable Ecosystems (132- 138). Brisbane, AUS: Centre for Conservation Biology University of Queensland

Muhammad, S. V. (2012). Illegal Fishing di Perairan Indonesia: Permasalahan dan Upaya Penanganannya secara Bilateral di Kawasan. Jurnal Politica, 3(1), 59-85. DOI: 10.22212/ jp.v3i1.305

Peraturan Menteri Kelautan dan Perikanan Nomor 56 Tahun 2014 tentang Penghentian Sementara (moratorium) Perizinan Usaha Perikanan Tangkap di Wilayah Pengelolaan Perikanan Negara Republik Indonesia. Berita Negara Republik Indonesia Tahun 2014 Nomor 1724

Peraturan Menteri Kelautan dan Perikanan Nomor 10 Tahun 2015 tentang Perubahan atas Peraturan Menteri Kelautan dan Perikanan Nomor 56 Tahun 2014 tentang Penghentian Sementara (moratorium) Perizinan Usaha Perikanan Tangkap di Wilayah Pengelolaan Perikanan Negara Republik Indonesia. Berita Negara Republik Indonesia Tahun 2015 Nomor 616

Nuraini, D. (2020). Satu persatu Beleid Era Susi Pudjiastuti akan Ditenggelamkan Edhie Prabowo. Retrieved from: https://ekonomi.bisnis.com/ $\mathrm{read} / 20200226 / 99 / 1206089 / \mathrm{satu}$-persatu-beleid-era-susi-pudjiastuti-akan-ditenggelamkan-edhy-prabowo

Nurlaili, Muhartono, R., \& Hikmayani, Y. (2016). Dampak Kebijakan Moratorium Terhadap Sektor Usaha Perikanan Tangkap di Kota Bitung. Jurnal Kebijakan Sosial Ekonomi Kelautan dan Perikanan, 6(2),145-152. DOI: http://dx.doi. org/10.15578/jksekp.v6i2.3327

Saptanto, S., Yusuf. R., Apriliani, T., \& Arthatiani, F. Y. (2015). Analisis Dampak Moratorium Kapal Eks Asing Terhadap Kondisi Pasar Tuna Indonesia. Jurnal Kebijakan Sosial Ekonomi Kelautan dan Perikanan, 5(2), 137-146. DOI: http://dx.doi. org/10.15578/jksekp.v5i2.1028
Shivlani, M. P., Milon, J. W., (2000). Sociocultural effects of a market-based fishery management program in the florida keys. Coastal Manage, 28(2), 133-147. DOI: https://doi.org/10.1080/089207500263558

Syahrani, D. A., Al Musadieq, M., dan Darmawan, A. (2017). Analisis Peran Kebijakan Illegal, Unreported, and Unregulated Fishing (IUU) Pada Ekspor Ikan Tuna dan Udang Tangkap. Jurnal Administrasi Bisnis, 45(1),27-36. Retrieved from: http://administrasibisnis.studentjournal.ub.ac.id/ index.php/jab/article/view/1748

West, R. J., Palma-Robes M. A., Satria, F., Purwanto., Wudianto., Sadiyah, L., Prasetyo A.P., Faizah, R., Setyanto, A. (2012). The Control and Management of Illegal, Unreported and Unregulated (IUU) Fishing in Fisheries Management Area 573. Report Prepared for ACIAR Project FIS/2006/142, Developing New Assessment and Policy Frameworks for Indonesia's Marine Fisheries, Including the Control and Management of Illegal, Unregulated and Unreported (IUU) Fishing. Australian National Centre for Ocean Resources and Security (ANCORS). Retrieved from: http://exchange. growasia.org/system/files/Developing $\% 20$ new $\% 20$ assessment $\% 20$ and $\% 20$ policy $\% 20$ frameworks $\% 20$ for $\% 20$ Indonesia's $\% 20$ marine $\% 20$ fisheries $\% 2 \mathrm{C} \% 20$ including $\% 20$ the $\% 20$ control $\% 20$ and $\% 20$ management $\% 20$ of $\% 20$ Illegal $\% 2$ C $\% 20$ Un.pdf 